\title{
14
}

\section{Historicising culture: Father Ernst Worms and the German anthropological traditions}

\author{
Regina Ganter
}

When the shy and unobtrusive, often trembling, Catholic Father Ernst Worms $(\mathrm{SAC})^{1}$ arrived in Broome at the end of 1930 and was asked 'and how do you like Broome, Father?', he responded with polite lies and presumably told his interlocutors what he thought they might like to hear. What he would have liked to tell them was that it was 'gross'. He saw a society divided along the minute spatial geographies of race and class, and thoroughly exploitative. He sent his mentor in Limburg a West Australian pocket yearbook with the comment:

[L]ook at the high wages in Broome, whereas the non-whites, i.e. blacks, half-castes, Chinese, Malays, and Japanese, are given dogs' wages [werden mit einem Hundelohn abgespeist]. Blacks are almost always given $£ 1$ a month! The government doesn't care. ${ }^{3}$

\footnotetext{
1 Worms later Anglicised his Christian name to Ernest. SAC stands for Society of the Catholic Apostolate, colloquially referred to as the Pallottines, named after their Italian founder, (Saint) Vincent Pallotti. The author acknowledges the assistance of the Australian Research Council Future Fellowship ARC FT100100364.

2 Kurt Benesch, Mission Aktuell 1/1975, in Worms, Ernst, P. (1891-1963), pp. 1-27, Zentralarchiv der Pallottinerprovinz [hereinafter ZAPP], Limburg.

3 Worms to Nekes, Broome, 22 March 1932, in Nekes, Australien B7d, 1(2), ZAPP.
} 
Worms's unpublished writing was often crafty, witty with a dry humour and gentle in his appraisal of the foibles of his brethren. He tried to live up to the expectations of his superiors as the pioneer of a new age of missions.

Father Worms (1891-1963) was the first of the Pallottine stormtroopers of the Prefect Apostolic in the Kimberley, Father Otto Raible (SAC), who had a grand vision for an expanded Pallottine presence in the Kimberley. In 1935, Raible became the first Pallottine bishop in Australia. The German Pallottines had been in the Kimberley since 1901, but it took until 1935 before they were awarded the ecclesiastic administration of the Kimberley vicariate. Raible defended their sphere of influence on two major fronts: against the competing Spanish Benedictines based at New Norcia, who had challenged the presumed Pallottine territory with their Drysdale River Mission, and against the increasing intervention of a secular state bureaucracy claiming absolute control over Aboriginal affairs in Western Australia. Raible's new age of mission involved the acquisition of a productive farm in the emerging southern wheatbelt (Tardun); the (short-lived) introduction of two experts in tropical medicine from the Würzburg institute for mission medicine, a Catholic college founded in 1922 (Leugers 2004: 112), ${ }^{4}$ Dr Johann Betz and his wife, Ludwina BetzKorte; ${ }^{5}$ the introduction of a professor of linguistics from the Orientalist Seminar in Berlin, set up to train public servants in the German empire, Dr Hermann Nekes (SAC); and the establishment of a theological training college in Kew, Melbourne. The last initiative resulted in a generation of Australian-born Pallottines and stood the Society of the Catholic Apostolate (SAC) in good stead during and after World War II and eventually assisted the shift from remote Indigenous mission to urban youth work inspired by the German Pallottine Schoenstatt movement, which focused on the involvement of laity. The Pallottines in Melbourne became strongly involved with Catholic Action, an anti-communist movement associated with Bob Santamaria that caused the Labor Party split in 1956 (Nailon 2001: 161-3).

Worms, trained in the Schoenstatt tradition, had been associated with a similar youth initiative after his ordination in 1920, when he was stationed near Königsberg to minister to Neudeutsche ('new Germans') after the redrawing of national boundaries at the end of World War I (Ihle 1968: 405-27). Worms received two months of training in mission

4 For the Würzburg institute, see: www.medmissio.de/.

5 'Betz, Johann Dr and Ludwina Betz-Korte', in Ganter (2016). 
medicine at the Würzburg college before he travelled to Australia in November 1930 on the German Lloyd ship Trier, which carried almost 100 German missionaries of different denominations to Singapore, destined for various parts of the Asia-Pacific. ${ }^{6}$

Worms's training in theology and philosophy at Limburg reflected the intellectual traditions of the German universities. ${ }^{7}$ He commenced his Australian research very much within the vision explicated by Rudolf Virchow regarding the capacity of missionaries to inform, collect and research, which formed part of the German instructions for scientific travellers and collectors that left the theorising to the metropole and favoured the recording of observations in the field 'uncontaminated by theory'. ${ }^{8}$ Worms began his work in the Kimberley with wideranging scientific observations. For at least the first three months in Broome, he meticulously recorded the weather, including temperature, cloud cover, wind direction, rainfall and any unusual phenomena. He inspected a petrified tree (at a place recorded as Ten Mile Mill) and followed up on reports of a figure of Christ appearing in the intertidal zone. He also visited the Port Hedland rock art galleries already described by Elkin and Basedow and subject to much discussion and speculation.

Worms spoke German, English, French and Latin and his theological training in Limburg had included linguistic training (1918-20) from Hermann Nekes (SAC), who was known for his work in Cameroonthe major field of Pallottine involvement-on tonology and foreign influences in the Bantu languages. During his first year in Broome, Worms began working on the Yawuru language under the guidance of Nekes in Limburg. Worms was very awake to the cultural influences and dramatic changes being wrought on the Kimberley communities by the lugger industries that brought many Asians to the northern ports and provided easy mobility for its Indigenous workers. Broome, in particular, had become a second home to many workers from Timor, Rote and other nearby islands (Yu 1999: 49-73). By May 1933, Worms urgently requested a Malay grammar. The core of his work became the attempt to decipher layers of cultural influences on the roadmap of the diffusionist

6 Josef Schüngel SAC to Bernd Worms, 2 August 1988, in Worms, Ernst, P. (1891-1963), pp. 1-27, ZAPP.

7 See, for example, descriptions of the training in Dresden and Neuendettelsau by Christine Lockwood (2014) and Anna Kenny (2013), respectively, and under the menu item 'MoreMissionary training' in Ganter (2016).

8 Virchow (1888), discussed in Murray (2004: 130-42). See also Janice Lally (2008: 191-215). 
and historicising German ethnographic tradition that survived until the 1950s and 1960s (Gingrich, Chapter 2, this volume), and it was this theoretical cage that prevented Worms from accepting the many voices arguing for extraneous influences on Aboriginal cultures and languages.

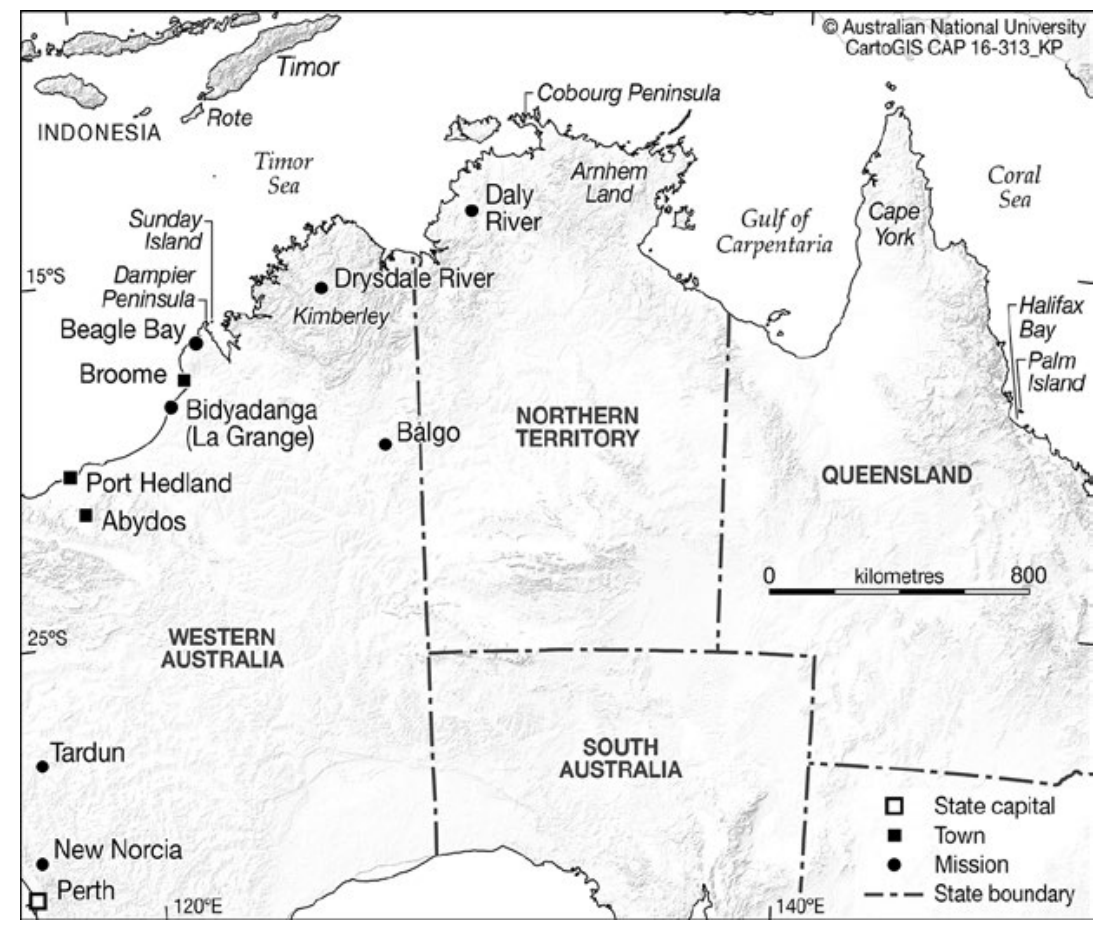

Map 14.1 Locations mentioned in the text.

Source: CartoGIS, The Australian National University.

Not a Malay grammar, but Nekes himself arrived in the Kimberley in 1935 with the newly appointed Bishop Raible. Nekes was very familiar with the work of Father Wilhelm Schmidt (SVD: Society of the Divine Word). Schmidt was founder and editor of the Anthropos journal, president of the International Congress of Anthropological and Ethnological Sciences and founder of the papal missionary ethnological museum in the Lateran Palace in Rome. Schmidt was known for his contribution to the study of the language families of the world, with the identification of the Mon-Khmer language as a link between Asian and Austronesian languages. Schmidt's eight-volume Ursprung der Gottesidee (The Origin of the Idea of God, 1955) asserted monotheism as the condition of primitive religions, and he subscribed to the idea of pygmy races as an Urvolk 
observable across the world - an idea that had emerged in Germany in the 1890s and was also adopted by Norman Tindale and Joseph Birdsell (1941). ${ }^{9}$ Implicit in Schmidt's work was the deeply held assumption, shared with his German-speaking contemporaries, that language reflected the Volksgeist, so that language, culture and religion formed a cohesive cultural complex (Gingrich, Chapter 2, this volume; Kenny 2013).

These four ideas are mirrored in the work of Worms without being explicitly theorised: 1) an affirmation of a basic unity of Aboriginal languages, as distinct from the Tasmanian languages, which were ascribed to 2) a prior $U r$-population, 3) traces of monotheism in these older cultural strata, and 4) the idea of the centrality of language in expressing and communicating culture. Worms did not see it as his task to develop new theories, only to map his findings on to the contemporary credible explanatory paradigms.

It was Schmidt's (1919) work on the structure of Australian languages that led Worms to think of his magnum opus on Australian religion along the fault lines of a significant distinction between 'Australian' and 'Tasmanian' religions as a working title for his book. ${ }^{10}$ In 1962, Worms was 'just polishing' the manuscript, expecting an imminent publication; alas, the book did not appear until after his death, heavily edited and reconceptualised with the fault lines flagged in the title shifted for a more modern audience to 'Australian' and 'South Pacific' religions. ${ }^{11}$ Worms had already realised in 1958, when he reviewed Arthur Capell's book on Australian languages, that Schmidt's structure of Australian languages was 'no longer tenable', but it was too late for him to rethink his book on religions and he could not give up the underpinning idea of migration and diffusion that had scaffolded all his work. ${ }^{12}$

9 Schmidt's urgent appeal in 1910 to study the pygmy races is discussed in Gusinde (1957).

10 Worms had as a working title 'Die Religion der australischen und tasmanischen Eingeborenen' (The religion of the Australian and Tasmanian Natives).

11 The work was published as Worms and Petri (1968).

12 In his book review, Worms conceded that the Victorian languages were not as archaic as Schmidt thought and that there was little evidence of a southward movement of the Victorians, nor could the Victorian languages be considered a block. Aranda, on the other hand, could not be considered an erratic appearance in the Australian languages as Schmidt had thought. A relationship between the Tasmanians and the northern Queensland pygmoids could not be established and it was likely that the languages that had developed in Victoria represented an autochthonous development that rendered Schmidt's theory of waves of migration untenable (Worms 1958). 
Schmidt, in common with the weight of opinion among German ethnographers in the nineteenth century, was strongly anti-evolutionist, resisting the idea of a progression of humankind from primitive to cultured. One of Schmidt's disciples, Wilhelm Koppers, sent Worms a copy of a little-known 1959 German publication on 'the error of Darwinism' (Nachtwey 1959), which expressed the anti-evolutionist stance they all shared. ${ }^{13}$ Worms felt that the German 'new ethnology' of Ratzel, Graebner, Frobenius and Schmidt 'harmonised with Catholic thought', because it resisted evolutionist thought and therefore made room for the Christian creation story, and because it affirmed the existence of monotheistic conceptions in primitive cultures rather than positing a unilinear development from atavistic to polytheist and finally monotheist religions. In one of his populist publications in 1947, Worms single-handedly dismissed the work of Frazer, Tylor, Spencer and Morgan as 'pre-modern ethnology' 'enslaved to evolutionism' and craftily asserted that only the English scholars ('except for Andrew Lang') still lagged behind 'new ethnology' (all of which was in German). He leaned on Max Müller's ideas about the 'heaven fathers' of ancient European societies to refute allegations by Australianists such as Howitt that the 'missionaries had invented the high God' in their interactions with Indigenous people (Worms 1947: 11).

Clearly, Worms's ethnography was driven by the desire to comprehend Aboriginal religion in terms that were decipherable to Christian thought. The basic, though largely implicit, tenet of Worms's work was that in the Kimberley an older stratum of beliefs included an all-father, who was public knowledge and could be freely referred to, and this was over-layered with more recent influences from the geographic centre (Worms 1955a). He observed about the Bardi that they practised monogamy and their initiation involved the knocking out of a tooth (Worms 1938a). He also discerned in the Bardi language a morphological connection between the word for sun and terms associated with initiation, and therefore supposed that the older culture may have had a sun-worshipping component (one of the 'lemes' identified by McGregor, in Chapter 13, this volume, as a linguistic technique used by Worms). All of these characteristics were taken as indicators of an older culture observable in the Kimberley in keeping with Schmidt. A shared and identifying element of the newer

13 This book, along with many others gifted to Worms by his German colleagues, even well after his retirement, remains in the library of the Pallottine house in Kew to which Worms retired. 
ideas, stories, ceremonies and objects was that they were protected with restrictions and secrecy. Worms deciphered this diffusion through comparisons with the findings of Ronald and Catherine Berndt from Arnhem Land and of Carl Strehlow on the Aranda and Loritja/Gogadja. Worms gradually adjusted his orthography to that of these three authors, leaving behind his initial adherence to Schmidt's Anthropos alphabet, which was not favoured by English speakers, so Bād became Bard, N'olN'ol became Njul-Njul, Jaueru became Yaoro and Gorañara became Guranara, more akin to Berndt's Kurangara, a recent ritual complex to which Worms devoted much thought. Worms remained strongly devoted to the Kulturkreislehre ('culture circle theory') concept of Schmidt and Koppers, which he romanticised as a methodological tool:

[We] must use historical culture-circle method, a very complicated and exacting technical procedure which could be compared to the work of a geologist in determining relationships and stratifications in the earth.

(Worms 1947: 11)

Worms used every methodological instrument available to him-oral history, legends, observations of culture, language morphologies and, finally, rock art- to decipher diffusion, and attempted to place changes in a historical framework to match them with these German theoretical approaches.

A detailed description of the stages of initiation (published in German in 1938a) emphasised several Kulturkreis elements. ${ }^{14}$ The quartz knives used had been brought from the mountainous inland and had the same name on the coast and in the desert. Several of the ceremonies required the collaboration of people other than one's own, and the ceremony of the Karajarri he witnessed was held on mission land much further north, outside their territory (Worms 1938a, 1938b). Elsewhere, Worms also noted that, among the Bardi, the four-week-long preparatory instructions taught the young men ceremonial words for everyday objects-often obsolete or foreign words (Worms 1950a). One of the Karajarri initiation songs could not be translated as the performers claimed not to understand the words. It was just the same with initiation songs of the Bardi, Dyaro and Nyulnyul, and Worms commented that he often encountered this with regard to texts that had been imported along the Fitzroy River.

14 Worms specified that he studied Karajarri (Garadyari at La Grange, Cape Bossute), Yawuru (Yaoro around Broome), Bardi (Baad at Lombadina), Nyulnyul (Beagle Bay), Jaru (Dyaro, south of Halls Creek) and also Walmajarri (Walmadyeri/Warmala, towards Gregory Salt Lake). 
This comment served to support his suggestion of a cultural diffusion from the centre, but Worms omitted to mention that Strehlow had already described the same phenomenon — of a secret ritual languageamong the Aranda. ${ }^{15}$

Worms managed to translate the Nyulnyul song and sent it, together with a wax cylinder, to Marius Schneider at the Völkerkundemuseum in Berlin. He realised early that the explanation that a text had come from elsewhere, and could therefore not be translated, might be a layer of protection. With regard to the curse incantations of the Kurangaral Gorangara complex, he wrote:

This supposed untranslatability, and the endeavour to ascribe the origin of a curse song to another group of people, stems from the desire to protect a larger secret and leave to a distant tribe the odium of having created such a supposedly gruesomely effective saying. (Worms 1940: 221) ${ }^{16}$

Still, he lent much credibility to explanations of texts, objects and ideas as 'coming from the east'. Worms showed one tjuringa (he used the Aranda term with Strehlow's spelling) that was given to him (possibly his first) to several different people, all of whom gave somewhat different explanations of it. One said it had come from the Nykina (neighbours towards the east), one said it had come from the Ngarinyin (located in the north-east) and another said it had come from the Walmadjeri (located in the south-east) (Worms 1950a: 641-58). It is not clear whether the informants referred to the object itself, the meaning inscribed on it or the very idea of the tjuringa, as a cultural import. (Worms was well aware that tjuringa were also made locally.) Worms used this range of information on the same object to show the ubiquity of explanations of things 'coming from the east'. (In my opinion, a subject position on the west coast of a peninsula on the West Australian coast almost dictates that practically everything comes from the east—even if just a little further east, such as Galalang coming from Sunday Island.)

15 'Teil Das Soziale Leben der Aranda und Loritja, I. Abteilung' in (Strehlow 1907-20: Vol. IV, pp. 28-32) and 'II. Abteilung' (Vol. II, pp. 47-54).

16 'Diese angebliche Unübersetzlichkeit und das Bestreben, die Herkunft der Fluchgesänge einem anderen Volke zuzuschreiben, entspringt dem Wunsche, ein grösseres Geheimnis zu schützen, und das Odium der Urheberschaft eines nach ihrer Ansicht so grausig wirksamen Spruches einem entfernt wohnenden Stamme zu überlassen.' 
Because of frequent references to influences coming from the east, and because of his theoretical mind map, Worms consistently discounted a cultural influence from the north. For example, in response to a study by Daniel Sutherland Davidson arguing that the fire saw had been imported 'from the direction of Timor' (Davidson 1947), Worms published an alternative explanation in the same year in which Griffith Taylor also reaffirmed a much older pygmoid migration from New Guinea or the Philippines (Winlow 2009). Worms agreed that the fire drill was the older technology, not subject to any restrictions, and that the fire saw was a more recent introduction and was used only by elder males. Worms had visited the so-called pygmy tribes of Halifax Bay and Palm Island and found that one of these groups did not have the fire saw. He also determined that the words for fire were similar between these north Queensland languages and those of Tasmania and the Kimberley (Worms 1950b). This observation is suggestive of the pygmy migration theory embraced by Schmidt, which imagined this older civilisation pushed to the margins of the continent. Worms agreed with Davidson that the older fire drill must have accompanied the 'earliest migration' from Cape York towards the west. But he discounted a South-East Asian origin for the fire saw-first, because it was also known to the eastern pygmoid people at Palm Island and Cape York; and second, because the Nyulnyul assured him that the fire saw had come to them from the east. On the basis of a comparison of 29 languages in the Kimberley, New South Wales and north Queensland, Worms assumed that the fire saw was imported from the southern suffixing languages, ultimately from Central Australia (Aranda), and had moved northwards across the Dampier Peninsula (Worms 1950b).

Worms's language morphologies were imaginative (see McGregor, Chapter 13, this volume), but, trapped by theory and a literal understanding of oral history, he never sought the same kinds of ('lemic') similarities between Australian and Malay languages. By Worms's own method, one might find the similarity between garidja, the mythical eagle ancestor that brought fire to the Bardi, according to Worms, and garuda, the Indonesian term for eagle deriving from Sanskrit, where it denotes a mythical bird-man, at least striking, and would begin looking for similar word/meaning pairs, perhaps at Cobourg Peninsula, where Father Confalonieri had already undertaken significant language work.

Similarly, although Worms recognised that circumcision and subincision (and the four-class marriage system) had been adopted in the Kimberley in the not too distant past, he ignored the potentially extraneous origin 
of some of the words given to him for the stages of male initiation. For example, at the second stage of initiation, a young man was called nindi or orongganyano. With recourse to a Malay grammar, Worms might have found the first part of the alternative term suggestive of the Indonesian word orang ('man'/'person'). The fifth level was described as bungana, not unlike the term bunggawa used in the trepang fishery for 'headman' and related to the term abang for 'elder brother'-an Indonesian respectful address (Macknight 1969, 1976). At Elcho Island, where a succession of elders have liberally revealed the Macassan connection, the secret-sacred language used in rituals was explained as a form of Malay (or at least containing many Malay words), the language that was also used to address the first Europeans in the Top End. ${ }^{17}$

Elders in the Kimberley have made no such disclosure and, at any rate, the theory underpinning the work of Worms did not countenance such an extraneous influence. The cultural and linguistic similarities between the Kimberley and the centre that Worms found reflected in the work of Carl Strehlow suggested a Central Desert origin for most phenomena that he identified in the Kimberley as more recent. He concluded that there were many signs of the imposition of a Central Australian culture on the more primitive north-west Australian culture (Worms 1950b). By more primitive, he meant an older culture that was less complex than the contemporary one, rather than undeveloped in the evolutionist sense.

Worms published 50 Kimberley legends in German (1940) to which he referred as migratory myths and plumped these for religious ideas. $\mathrm{He}$ attempted to arrange the various culture heroes in historical order of arrival in the Kimberley (Djanba - Djamar - Minau or Bamar - Galalang). This attempt at theorising (Worms 1952) is not very convincing, ${ }^{18}$ perhaps because the project was upended by the regional 'nicknames' with which

17 Interview with Terichini Yumbulul, Galiwin'ku, Northern Territory, June 1995. He was the son of David Burrumarrra, a chief informant for the Berndts, Ian McIntosh, Peter Spillett and others regarding Macassan contact (McIntosh 1994; Ganter 2006: 42, and passim).

18 Djamar is judged to be extraneous although he was said to have come to Lombadina from (nearby) Sunday Island. Galalang, thought to represent the oldest and 'indigenous' stratum, was also described as having come from Sunday Island (like Djamar) when the informant was only a boy. Minau, also referred to as Bamar, were said to have introduced obscene dances as well as polygamy, circumcision and subincision (and therefore sound more like a composite of Djanba and Djamar). The Bardi informants (but not the Nyulnyul) thought Galalang's times were better, which suggests that Galalang's times had only recently receded, so that a two-tier cultural shift, rather than a four-tier one, seems a more credible interpretation of Worms's results. One Bardi man referred to the people at Cossack (pearling harbour) as cannibals, indicating that they had very different customs from the Bardi, and he himself preferred the 'olden time', related to Galalang (Worms 1952). 
Luise Hercus also struggled in the Diyari legends. ${ }^{19}$ Djanba, the most recent introduction, was associated with the 'Gorangara cult', which Worms and Bishop Raible first encountered near Balgo in 1938. Worms described it as an immoral, dangerous cult of black magic that was spreading across the Kimberley, striking fear into people. Worms had no inkling that it was a contact cult directed against colonisation (Redmond, Chapter 16, this volume), just as the Jesuit missionaries on the Daly River had observed the Tyaboi in the 1890s without any idea that they themselves featured in its ritual enactments (Rose 1998).

Missing from Worms's historical line-up of culture heroes in 1952 was Djanggala, the supernatural being of the Kimberley, which Worms thought was a local version of Djanggawul, reported by Berndt in Arnhem Land. The Berndts were supplying ample evidence of a lively contact and traffic between Makassar and south-east Arnhem Land that had ended only in 1906, including the oft-cited story of Djalajari, who had spent many years in Makassar and had a family there (Ganter 2006: Ch. 2). But the Berndts rendered Macassan terms in unrecognisable spelling, often unsuspecting of a Malay origin of words they took to be Yolngu-matha. For example, the Berndts refer to a place in Arnhem Land as 'Libabandria' without realising that this is the Macassan name Lembana panrea (meaning Tradesmen's Bay) adopted into Yolngu-matha. Kampung Maluku, a district of Makassar, is rendered as Kambu'malagu, Captain Daeng Tompo appears as 'karei Deintumbo buga' (which includes both karaeng/'king' and bunggawa/'headman'). Captain Husein Daeng Rangka, also known as Jago ('fighting cock'), appears in Djalajari's story recorded by Berndt as Captain Jadjung, identifiable by his vessel, the Patti Jawaya, written as Batadjowa. ${ }^{20}$ Similarly, among the 43 terms Mawulan gave to Berndt in 1947 for objects and parts of a lugger, there are also recognisably Indonesian words such as gula ('sugar') for syrup, rendered

19 Luise Hercus (Chapter 5, this volume) referred to some of the mura-mura recorded by Reverend Georg Reuther, which she was able to identify only through reference to the work of Spencer.

20 Other Macassan placenames in Arnhem Land were Lemba Moutiara (Pearl Shell Bay) and Lemba Bingangaja (Trepang Bay). The Yolngu also adopted the Macassan placename of Kodinggareng Island for Gunyanggarra (aka Ski Beach at Yirrkala), and Garra-mangalai in Caledon Bay (aka Grays Bay) derives from Karaeng Mangnellai (King Mangellai, referring to the genealogy of the Macassan captain Mangellai Daeng Maro) (Ganter 2006: Ch. 2; Macknight 1969: 180-5; Berndt and Berndt 1954: 53). 
as gwula. ${ }^{21}$ What all this means is that the rendition of an unrecognised loan word must be read with some latitude (for example, Djalajari is also rendered as Charley Charley).

Worms's guiding theories prevented him from casting his inquiries towards such extraneous influences from the north, though he well knew that contact between different Aboriginal groups in the lugger industries had produced a bewildering array of new customs and ideas. ${ }^{22} \mathrm{He}$ assumed that the starting point of introduced terms and customs was somewhere in South Australia and the Central Desert, but he was, at this early stage of Australian linguistics, unable to draw on a consistent method to identify the changes to which word stems had been subjected. Much more recently, Nicholas Evans's study of Macassan loan words at Cobourg Peninsula, based to a large degree on the work of Father Angelo Confalonieri in the 1840 s, found that the Iwaidjan languages are the 'linguistic equivalent of a well-stratified archaeological language site' (Evans 1997: 239). Evans uses a credible methodology for identifying linguistic adaptations, whereas, 50 years earlier, Worms was casting around, guided by the methods of Nekes and Schmidt (see McGregor, Chapter 13, this volume).

It was the Frobenius Expedition in 1938-39 that directed Worms'sattention to rock art as a way of deciphering historical layers of culture. Before their arrival, Douglas C. Fox, the American journalist who accompanied the expedition and who had mounted an African and European rock art exhibition at the Museum of Modern Art in New York in 1937 with Leo Frobenius, sent the accompanying book to Bishop Raible. ${ }^{23}$ Leo Frobenius had founded the Research Institute for the Morphology of Civilisations in 1923 (and the Deutsche Gesellschaft für Kulturmorphologie), a fringe school of thought hotly discussed in Germany but virtually

21 Not being familiar with Malay, Makassar or other regional languages, I am only able to identify Indonesian words. When I pointed out the gula/gwula similarity in a personal communication at the Berndt Museum in 2013, Sandy Toussaint's Indonesian-speaking assistant was able to identify further Indonesian words in the same document: Mawulan's drawing on butcher paper, June 1947, Berndt Collection, Nr. 7246, Berndt Museum of Anthropology, Perth.

22 Worms observed that much of this circulation of culture arose from the work on the pearling luggers and innovations were still within living memory. For example, the two-class skin system of the Kimberley had been replaced with the four-class system (of the Aranda, according to Worms) through contact with Ngamula people at Cossack since the 1870s (Worms 1952).

23 This book, with a dedication by Fox, is held in the Pallottine library in Kew (Frobenius and Fox 1937). 
unknown elsewhere. ${ }^{24}$ The idea of cultural morphology sat well with the historicising diffusionist empiricism also present in Schmidt, at least in methodological terms. The Pallottines welcomed this expedition to their northern missions and, in Worms's biographies, his role in the Frobenius Expedition is somewhat overstated, suggesting that Worms facilitated or hosted the expedition..$^{25}$ In fact, Frobenius was unable to accompany the expedition, and Helmut Petri's book arising from it makes little reference to Father Worms, other than a criticism of his 'Aranda origin' theory (Petri 1954). (Petri also omits to mention the Australian emerging scholar Arthur Capell, who accompanied them.) Worms met Petri on his arrival in the Kimberley (after which Worms and Raible set off to find an alternative site for the Rockhole mission in the desert area, later called Balgo) and again at the conclusion of Petri's northern fieldwork in January 1939. They also met many years later at the end of Worms's own WennerGren Foundation-funded fieldwork in October 1960, when Worms met up with Petri and Gisela Petri-Odermann at La Grange mission to record Garadjeri (Karajarri) songs, ${ }^{26}$ and presumably also during Worms's German lecture tour in 1947.

Petri and Lommel's exhibition of Aboriginal rock art in London in January 1947 received much attention (Worms 1953b) and spurred Worms into further work on northern Australian rock art, which was also receiving increasing attention in Australia (Basedow 1925; Elkin 1930). Unlike the visitors from overseas and the south, he was able to position himself as the resident expert, and based himself in Broome again for a WennerGren Foundation research grant in 1953 and 1954 to decipher layers of cultural periods from petroglyphs and pictograms. He revisited the rock art galleries at Port Hedland and galleries in the Abydos/Woodstock area of the Pilbara, along the Gibb River and near Kalumburu. Worms became

24 Professor André Gingrich explained that the Frobenius school of cultural morphology might be characterised as a neo-Herderian German romanticism with an anthropomorphic frame that focused on cycles of emergence, maturity and decay of cultures. In a personal communication, he added that it was somewhat 'fringe'. See Gingrich (Chapter 2, this volume).

25 News reportage emphasised Worms's role in hosting the Frobenius Expedition. For example: 'Dr. Petri, of the Frankfort Ethnological Museum, who is the leader of the Frobenius expedition for the comparative study of primitive and prehistoric culture, will arrive to-day by the overland express. He made thorough researches of the cave paintings in the north of Western Australia. Dr. Petri will be the guest of Father Rector Worms, of the Pallottine Missionary College, Kew' (The Argus, [Melbourne], 10 January 1939: 6). See also 'Kimberley natives', West Australian, [Perth], 7 November 1938: 16.

26 Worms, E. P., Cahiers du Terrain, Musée National des Arts Africains et Océaniens, (fieldnotes, in German), Microfiche held by the Australian Institute of Aboriginal and Torres Strait Islander Studies (AIATSIS), Canberra. 
the first to describe some sites near the government research station at Abydos/Woodstock, later called Father Worms Hills, and counted his work on rock art as his most significant contribution to science. Although Worms does not make this explicit, it is reasonable to assume that his ways of seeing rock art were by now guided by the work of Frobenius, Petri and Lommel. What he saw was 'a succession of aboriginal and ethnic migrations' (leaning now on ideas of migration rather than diffusion). At Gallery Hill, the depictions of sexual acts were confined to the upper stratum of the 'Woodstock figures'. The absence of traces of the masculinist Gorangara cult from the lower strata of rock images confirmed that it could not be autochthonous and was clearly introduced. Worms also observed that the Gorangara had not yet reached Port Hedland.

One of Worms's missionary predecessors, the Spanish Father Nicholas Emo, had already produced a sketchbook of the giro-giro (Bradshaw figures, aka Gwion Gwion) at the Drysdale River Mission in 1909. ${ }^{27}$ These drawings had also been described in 1937 by C. P. Mountford, who felt that, along the northern coast, Aboriginal art had reached a higher state of development than elsewhere and presumed that this was through contact with Malay pearl and trepang fishers. Worms agreed that the style of the giro-giro figures was much more sophisticated than other rock art styles and most likely executed with a brush. But he did not accept a Malay influence, because the sheer number and ubiquity of these paintings 'render an esoteric isolation impossible'. Worms thought they were executed in a 'bushmanlike' manner and favoured a comparison with various African and Spanish rock art styles. He reported that the local owners claimed that the authors of these paintings, which had no relevance to them, were a people called giro-giro. Returning to the pygmy tribe thesis, Worms suggested that they belonged to 'a pre-Australoid', a 'negrito-Tasmanoid settler period' (Worms 1955b: $565 \mathrm{ff}$.). Worms cited a number of legends from different areas about a now extinct people of short stature. For example, he cited Strehlow on the story of the Tuanjiraka, small men who once lived north of the MacDonnell Ranges - again, without suggesting any connection to tua ('old') or tuan (a polite address in Indonesian) (Worms 1955b). If not

27 'Emo, Nicholas Fr.', in Ganter (2016). Worms erroneously claimed that 'Emu' had drawn these in 1905; however, Emo was not at Drysdale that year, so perhaps Worms had this from hearsay and never saw the sketches. They ended up in the Museum of South Australia, where they are ascribed to the ornithologist Gerald Hill, who visited the Drysdale River Mission in 1910. Emo's diary at that time refers to his work of copying the rock art-mostly while lying on low ledges — and expresses the fear that Hill may claim the work as his own. 
for the theoretical frame of reference supplied by Schmidt, the linguistic puzzle pieces of meaningful or accidental similarities could have formed a very different pattern for Worms. The once intriguing pygmy theory has certainly fallen into disfavour for lack of evidence, and, indeed, the idea of an older cultural stratum does not require a 'pygmoid' population. More recent work confirms a long period of desertion of the Kimberley between ice ages that may explain the traces of different cultural strata. Robert Bednarik now suspects a migration most probably from Timor or Rote about 60,000 years ago (Bednarik 2010). Julia Martínez and Adrian Vickers supply an overview of maritime mobility in eastern Indonesia in the historical past and speculate that 'the name Jawi' (neighbouring the Bardi on Dampier Land) 'may even come from reference to Indonesians' (Martínez and Vickers 2015: 49).

In 1953, Worms and Nekes's major work on Australian languages was finally being published (in microfilm), premised on the fundamental unity of Australian languages and religions. That year Worms also responded to Ronald Berndt's (1951) study of the Kunapipi complex in Arnhem Land, which included the suggestion that Kunapipi represented an Asiatic, preIslamic 'great mother' cult or a Macassan importation. Worms was aware that the dingo had come from South-East Asia 'in the mists of time' (Worms 1955a: 146), and he also observed that the bamboo trumpet described by Berndt was slowly progressing from the Northern Territory through the east Kimberley towards the west and the ceremonial pole had also made its appearance in the western Kimberley in two instances. However, Worms doubted that Kunapipi could be a Macassan importation, because the name Kunapipi was so strongly rooted in genuine Australian terms (Worms 1953a).

Worms's commitment to a basic homogeneity of mainland Aboriginal cultures that could be discovered through linguistic analysis prevented him from accepting the idea of foreign influences. He always returned to the idea that 'it must be endogenous' (Worms 1953a) in the sense that whatever it was that he was examining must have originated from somewhere on the Australian continent.

Worms's period of publications commenced in 1938 when he became the rector of the Pallottine College in Melbourne after a fall from his horse that exacerbated a wartime injury and confined him to a corset, which made fieldwork in the tropical north all the more uncomfortable. At Kew he sought publicity for the missionary work of the Pallottines, who were 
breaking out of their sphere of influence in the Kimberley into the south. Worms tried to resist cultural stereotypes about Aboriginal people and attempted to insert a humanist perspective, always emphasising their equal intelligence in the framework of Pastor Herder's model of the unity of mankind. In a radio interview with the Südwestrundfunk (SWR), he went so far as to perform a corroboree song on air. While practically under house arrest in Kew during World War II, Nekes (1875-1948) and Worms produced their oeuvre on the Kimberley languages.

Worms also published the results of an experiment on the sense of smell, which Nekes had replicated from C. S. Myers of the 1898 Cambridge anthropological expedition to Torres Strait. Nekes had intended it as a linguistic experiment, but Worms used it to demonstrate that, against many assertions about the 'uncanny' overdeveloped sense of smell among Aborigines, there was no evidence of any hyperacuity among Indigenous people. Their sense of smell showed the same ranges of perception and agreement as that of white people and, moreover, was overdetermined by recent experiences. The greatest gender difference was the smell of tar, which Worms suspected may stem from the identity-forming experiences of men on the luggers, ${ }^{28}$ while women may associate luggers and tar with uncomfortable travel and sea-sickness. The greatest overall agreement was on the smell of incense, and Worms was quick to accede that this most likely stemmed from the use of incense in church (Worms 1942b).

Worms began his publication phase at the same time as Petri, with work in the Vatican's ethnological series Annali Lateranensi (1938a, 1940, 1942a and 1957b) and Oceania (1938b, 1942b), an Australian international journal established in 1931 and edited by the part-German Anglican rector Adolphus Elkin, who had a special interest in the Kimberley. However, in the early 1950s, one of Elkin's students, Mabel Wyllie, produced a scathing critique of Catholic mission policy. ${ }^{29}$ From that time, Worms eschewed Oceania and began to publish in the ethnographic journal Anthropos, founded by Schmidt (two in 1950, 1952, three in 1953, 1954, 1955, 1957, two in 1958, 1959, 1960, 1961). ${ }^{30}$ He produced two co-authored books, over 20 academic journal articles, several book chapters and many minor publications, including book reviews. Every publication required

28 On the sense of pride obtained through lugger work, see Ganter (1994).

29 Mabel Wyllie, 'A study of polygynous marriage with special reference to northern Australia ... and the attitude thereto of administration and Christian missions' (1952), cited in Erckenbrecht (2003).

30 For a full list of Worms's publications, see 'Worms, Ernst Fr.', in Ganter (2016). 
the prior approval of the Pallottine Provincial and was reviewed by two internal censors (Leugers 2004: 113). Nevermann commented that Nekes had brought photographic equipment from Germany in 1935, but Worms 'has hardly any photographs suitable for reproduction' (Worms and Petri 1968: 129). However, the Pallottine archives in Limburg and those in Rossmoyne (Perth) have many good-quality photographs, though unsorted and mostly without provenance. Worms curated the ethnographic exhibition housed until recently in the Pallottine mother house in Limburg, which included many of the objects he described in his publications, and several photographs in that exhibition (and presumably also many in the photo collection) were from Worms.

Worms gained an international reputation as a missionary anthropologist. ${ }^{31}$ During a series of lectures in the United States in April 1960, he participated in a symposium at a Central States Anthropological Society meeting in Bloomington, Indiana, speaking about the cultural changes wrought in Indigenous society, alongside the grand and emerging figures of Australian anthropology, Adolphus Elkin, W. E. H. Stanner, Catherine and Ronald Berndt, Jane Goodale, Arnold Pilling, Peter Worsley, Jeremy Long and others (Worms 1970). The following year, W. E. H. Stanner invited Worms to present at the conference that inaugurated what is now the Australian Institute of Aboriginal and Torres Strait Islander Studies. At age 69, Worms obtained a second Wenner-Gren research grant for a nine-month-long expedition to Central, northern and Western Australia during which he visited Ayers Rock (Uluru), the Simpson Desert and rock art sites in Arnhem Land, and saw bark paintings for the first time. His fieldwork journal mentions Bathurst and Melville islands, the northern coast and Mangingrida, Daly River, Port Keats, Katherine, Borroloola, Amoonguna, Alice Springs, Yuendumu, Papunya, Santa Teresa, Balgo and La Grange (mostly mission stations). In the process, he was organising

31 Worms followed invitations to speak in Rome, Munich, Münster, Vienna and at the Frankfurt Frobenius Institute, as well as the Smithsonian Institute in Washington, DC, the Verley University in San Francisco and the Congress of Anthropological and Ethnological Science in Philadelphia. In his last year, Münster University obtained funds from the DFG (Deutsche Forschungsgemeinschaft, the German equivalent of the Australian Research Council) to invite him back for a semester of guest lectures in the theological faculty, but he became too ill to travel and had to decline this and invitations from Cologne and Nijmegen. 
his ideas for his major oeuvre on Aboriginal religions. Religion was, after all, his area of expertise and the reason ethnography and linguistics were considered legitimate missionary tasks. ${ }^{32}$

Worms consistently discounted the impact of South-East Asian contact as a significant cultural factor and, rather, looked for the large-scale migration of ideas and people on the continent itself. Everywhere he found evidence of an intensive cultural and linguistic movement between the south-east and north-west of Australia, with 'relatively small and unimportant' traces of a foreign element from the East Indies (Worms 1957a: 762). Trying to make historical sense of the multitudinous cultural influences engulfing the Kimberley, Worms mapped his observations against contemporary theories. He was limited —as are we all—by his linguistic capacities, or else he might well have cast his net of imaginative language morphologies in very different directions and may have distanced himself from Schmidt's language structure much earlier. ${ }^{33}$ The pygmy migration theory was not essential for his assertions of diffusion, but it guided him into a search for historical layers of culture and cultural shifts.

Worms was deeply imprinted by Christian and German intellectual traditions that led him to a humanitarian approach to Indigenous people and to attempt to historicise cultural influences with a range of methods. The greater parts of his publications were in German and, since evolutionary theory has now lost its supremacist edge, Christian creationism has lost its interest in scientific discovery and migration theory has been muted by fears over native title implications, Worms's work has been marginalised, ${ }^{34}$ along with much of the work of German missionaries in Australia. For those interested in paradigm shifts, as well as for those interested in documenting attachment to place, there is still much to be discovered from the detailed empirical research left by Worms and other German missionaries, and my website on German missionaries in Australia attempts to render such work more easily accessible (Ganter 2016).

32 In his fieldwork diary, Worms noted pointers for inquiry ('religious indifference of the Australians?'), sources to which he wanted to refer and the major insights he wanted to demonstrate, such as 'the Australian indigenous expressions ("termini") are neither childish ways nor mere metaphors, but meaningful phrases_-see Jungmann II', or 'the wanjina board and string figures (gamba) in Kew and Manly are ancestor figures' (Worms, Cahiers de Terrain, AIATSIS).

33 In his book review of Capell, Worms (1953b) admitted that the central planks of Schmidt's structure of Australian languages were no longer tenable.

34 McGregor (2005: 16; 2007) determined that the dictionary produced by Worms and Nekes 'presents particularly important information on cultural practices and phenomena that have to my knowledge long since been forgotten'. 


\section{References}

Basedow, H. 1925. The Australian Aboriginal. Adelaide: F. W. Preece.

Bednarik, R. G. 2010. Australian rock art of the Pleistocene. Rock Art Research 27(1): 95-120.

Berndt, R. 1951. Kunapipi: A study of an Australian Aboriginal religious cult. Melbourne: Cheshire.

Berndt, R. and Berndt, C. 1954. Arnhem Land: Its history and its people. Melbourne: Cheshire.

Davidson, D. S. 1947. Fire-making in Australia. American Anthropologist XLIX: 426-37. doi.org/10.1525/aa.1947.49.3.02a00040.

Elkin, A. P. 1930. Rock-paintings of north-west Australia. Oceania 1(3): 257-79. doi.org/10.1002/j.1834-4461.1930.tb01649.x.

Erckenbrecht, C . 2003. Der Bischof mit seinen 150 Bräuten [The Bishop with the 150 wives]. Leipzig: Jahrbuch des Museums für Völkerkunde 41. pp. 303-322.

Evans, N. 1997. Macassan loans and linguistic stratification in western Arnhem Land. In Aboriginal Australia in Global Perspective, (eds) P. McConvell and N. Evans, pp. 237-60. Oxford: Oxford University Press.

Frobenius, L. and Fox, D. C. 1937. Prehistoric Rock Pictures in Europe and Africa. New York: Museum of Modern Art.

Ganter, R. 1994. The Pearl-Shellers of Torres Strait: Resource use, development and decline, 1860s-1960s. Melbourne: University of Melbourne.

Ganter, R. 2006. Mixed Relations: Asian-Aboriginal contact in north Australia. Perth: University of Western Australia Press.

Ganter, R. (ed.). 2016. German Missionaries in Australia. [Online.] Brisbane: Griffith University. Available at: missionaries.griffith.edu. au/biographies.

Gusinde, M. 1957. A pygmy group newly discovered in New Guinea: A preliminary report. Anthropological Quarterly 30(1): 18-26. doi.org/ $10.2307 / 3316681$. 
Ihle, R. 1968. 'Unter den Ureinwohnern Australiens': Biografie von Ernst Worms ['Among the Australian Aborigines': A biography of Ernst Worms]. In Pioniere und Aussenseiter - 21 Biografien [Pioneers and Dissidents - 21 Biographies]. Darmstadt: Turis Verlag.

Kenny, A. 2013. The Aranda's Pepa: An introduction to Carl Strehlow's masterpiece Die Aranda- und Loritja-Stämme in Zentral-Australien (1907-1920). Canberra: ANU E Press.

Lally, J. 2008. The Australian Aboriginal collection and the Berlin Ethnological Museum. In The Makers and Making of Indigenous Australian Museum Collections, (eds) N. Peterson, L. Allen and L. Hamby, pp. 191-215. Melbourne: University of Melbourne Press.

Leugers, A. 2004. Eine geistliche Unternehmensgeschichte - Die Limburger Pallottiner-Provinz 1892-1932 [A spiritual enterprise history - the Pallottine Province of Limburg 1892-1932]. St Ottilien: EOS Verlag.

Lockwood, C. 2014. The two kingdoms: Lutheran missionaries and the British civilizing mission in early South Australia. PhD thesis. University of Adelaide, Adelaide.

McGregor, W. B. 2005. Frs. Hermann Nekes and Ernest Worms's Dictionary of Australian Languages, Part III of 'Australian Languages' (1953). In Proceedings of the 2004 Conference of the Australian Linguistics Society, (ed.) I. Mushin. Sydney: University of Sydney. Available at: ses.library.usyd.edu.au/handle/2123/93.

McGregor, W. B. 2007. Frs. Hermann Nekes and Ernest Worms's 'Australian Languages'. Anthropos 102(1): 99-114.

McIntosh, I. 1994. The Whale and the Cross: Conversations with David Burrumarra MBE. Darwin: Historical Society of the Northern Territory.

Macknight, C. C. 1969. The Farthest Coast. Melbourne: Melbourne University Press.

Macknight, C. C. 1976. A Voyage to Marege: Macassan trepangers in northern Australia. Melbourne: Melbourne University Press.

Martínez, J. and Vickers, A. 2015. The Pearl Frontier. Honolulu: University of Hawai'i Press. doi.org/10.21313/hawaii/9780824840020.001.0001. 
Murray, B. 2004. Georg Balthasar von Neumayer's directives for scientific research. In The struggle for souls and science: Constructing the fifth continent-German missionaries and scientists in Australia, Occasional Paper No. 3, (ed.) W. Veit, pp. 130-144. Strehlow Research Centre, Alice Springs, NT.

Nachtwey, R. 1959. Der Irrweg des Darwinismus [The error of Darwinism]. Berlin: Morus.

Nailon, B. 2001. Nothing is Wasted in the Household of God: Vincent Pallotti's vision in Australia 1901-2001. Melbourne: Spectrum.

Petri, H. 1954. Sterbende Welt in Nordwest-Australien [The dying world of north-west Australia]. Braunschweig, Germany: A. Limbach.

Rose, D. B. 1998. Signs of life on a barbarous frontier: Intercultural encounters in north Australia. Humanities Research 2: 17-36.

Schmidt, W. 1919. Die Gliederung der Australischen Sprachen [The structure of Australian languages]. Vienna: Mechitharisten-Buchdruckerei.

Schmidt, W. 1955 [1912-52]. Der Ursprung der Gottesidee [The origin of the idea of god]. 12 vols. Münster: Aschendorff.

Strehlow, C. 1907-1920. Die Aranda- und Loritja-Stämme in ZentralAustralien. 7 vols. Frankfurt am Main: Joseph Baer \& Co.

Tindale, N. B. and Birdsell, J. B. 1941. Tasmanoid tribes in north Queensland. Records of the South Australian Museum 7(1): 1-9.

Virchow, R. 1888. Anthropologie und prahistorische Forschungen [Anthropology and prehistoric research]. In Anleitung $z u$ wissenschaftlichen Beobachtungen auf Reisen [Instructions for scientific observations on journeys]. Volume II, (ed.) G. B. von Neumayer, pp. 295-326. Berlin: Verlag von Robert Oppenheim.

Winlow, H. 2009. Mapping the contours of race: Griffith Taylor's zones and strata theory. Geographical Research 47(4): 390-407. doi.org/ 10.1111/j.1745-5871.2009.00604.x.

Worms, E. A. 1938a. Die Inititiationsfeier in NW-Australien [The initiation ceremonies in North-West Australia]. Annali Lateranensi 2: $147-74$. 
Worms, E. 1938b. Foreign words in some Kimberley tribes in Northwestern Australia. In Studies in Australian Linguistics, Oceania Monographs No. 3, (ed.) A. P. Elkin, pp. 165-70. Sydney: Australian National Research Council.

Worms, E. A. 1940. Die Religiöse Vorstellungen und Kultur einiger Nord-westaustralischer Stämme in fünfzig Legenden [The religious beliefs and culture of some nort-western tribes in fifty legends]. Annali Lateranensi IV(4): 213-82.

Worms, E. A. 1942a. Die Goranara Feier im australischen Kimberley [The Goranara festivity in the Kimberley of Australia]. Annali Lateranensi VI: 207-35.

Worms, E. A. 1942b. Sense of smell of the Australian Aborigines: A psychological and linguistic study of the natives of the Kimberley division. Oceania 13(2). doi.org/10.1002/j.1834-4461.1942.tb00373.x.

Worms, E. A. 1947. Primitives believed in one god not many. The Advocate, 5 March: 11.

Worms, E. A. 1950a. Djamar, the creator. A myth of the Bad (west Kimberley, Australia). Anthropos 45: 641-58.

Worms, E. A. 1950b. Feuer und Feuerzeuge in Sage und Brauch der NWAustralier. Anthropos 45: 145-64.

Worms, E. A. 1952. Djamar and his relation to other culture heroes. Anthropos 47: 539-60.

Worms, E. A. 1953a. Australian ghost drums, trumpets and poles. Anthropos 48: 278-81.

Worms, E. A. 1953b. Die Unambal: Ein Stamm in Nordwest-Australien [The Unambal: A north-west Australian tribe]. Man 53: 163-4.

Worms, E. A. 1955a. Bei den Australiern [Among the Australians]. Die Katholischen Missionen 5: 146-148.

Worms, E. A. 1955b. Contemporary and prehistoric rock paintings in central and northern Kimberley. Anthropos 50: 546-66.

Worms, E. A. 1957a. Australian mythological terms: Their etyology and dispersion. Anthropos 52: 732-68. 
Worms, E. A. 1957b. The poetry of the Yaoro and Bad. Annali Lateranensi 21: 213-29.

Worms, E. A. 1958. Capell's new approach to Australian linguistics. Anthropos 53(1-2): 270-1.

Worms, E. A. 1970. Observations on the mission field of the Pallottine fathers in north-west Australia. In Diprotodon to Detribalization: Studies of change among Australian Aborigines, (eds) A. Pilling and R. Waterman, pp. 367-80. East Lansing: Michigan State University Press.

Worms, E. A. and Petri, H. 1968. Australische Eingeborenen Religionen [Australian Aboriginal religions]. In Die Religionen der Südsee und Australiens [The Religions of the South Pacific and Australia], Vol. 5, No. 2, (ed.) C. M. Schroder, pp. 125-329. Stuttgart: W. Kohlhammer Verlag.

Yu, S. 1999. Broome Creole Aboriginal and Asian partnerships along the Kimberley coast. In Asians in Australian History, (ed.) R. Ganter, Queensland Review 6(2): 49-73. 
This text is taken from German Ethnography in Australia, edited by Nicolas Peterson and Anna Kenny, published 2017 by ANU Press, The Australian National University, Canberra, Australia.

dx.doi.org/10.22459/GEA.09.2017.14 